Münther, V. 1973: Results from a geological reconnaissance around Svartenhuk Halvø, West Greenland. Rapp. Grønlands geol. Unders. 50, 26 pp.

Nieland, H. 1931: Beitrag zur Kenntnis der Deckenbasalte von Westgrönland. Chemie der Erde 6, 591-612.

Pulvertaft, T. C. R. \& Clarke, D. B. 1966: New mapping on Svartenhuk peninsula. Rapp. Grønlands geol. Unders. 11, 15-17.

Walker, G. P. L., Wilson, C. J. N. \& Froggat, P. C. 1980: Fines-depleted ignimbrite in New Zealand the product of a turbulent pyroclastic flow. Geology 8, 245-249.

Geologisk Museum,

Øster Voldgade 5-7, $D K-1350$ Kobenhavn $K$.

\title{
Investigations on the Precambrian rocks of Svartenhuk Halvø, central West Greenland
}

\section{Bas van den Eeckhout and John Grocott}

Precambrian rocks occur within an area of $600 \mathrm{~km}^{2}$ in eastern Svartenhuk Halvø. A preliminary geological account of the southern half of this area is given here. The work is part of the mapping programme aimed at the production of the $1: 100000$ sheet $71 \mathrm{~V} .1 \mathrm{~N}$.

The Precambrian rocks east and south of Svartenhuk Halvø have been studied in some detail by Henderson \& Pulvertaft (1967), but until the summer of 1981, apart from the pioneering work of Steenstrup (1883) and preliminary petrographic descriptions of the metasediments by Noe-Nygaard (Rosenkrantz et al., 1942), the Precambrian of Svartenhuk Halvø had only been studied in the detail necessary for the production of the 1:500000 map sheet Mârmorilik - Melville Bugt. The map area consists of a gneissic basement with a metasedimentary cover (fig. 6).

\section{Metasediments}

The cover is dominated by a lithologically monotonous sequence of alternating metamorphsed sandstones and shales, called the Nûkavsaq Formation (Henderson \& Pulvertaft, 1967). Leucocratic, amphibole-bearing bands of uncertain origin lie parallel to bedding within the sequence. Good examples of sedimentary structures indicating the way-up are infrequent, but of these graded bedding is the most useful. Channelling was only observed at one locality, and no certain bottom structures survived the deformation. On each side of Kangiussap auvfâ in the southern part of the area the sediments have a marked brownweathered appearance and include garnet-mica schists, hornblende schists and quartzites. A similar but more varied sequence is present at the gneiss/sediment contact. Such rocks are exposed at the lowest structural levels within the cover, and may be members of the Qeqer- 


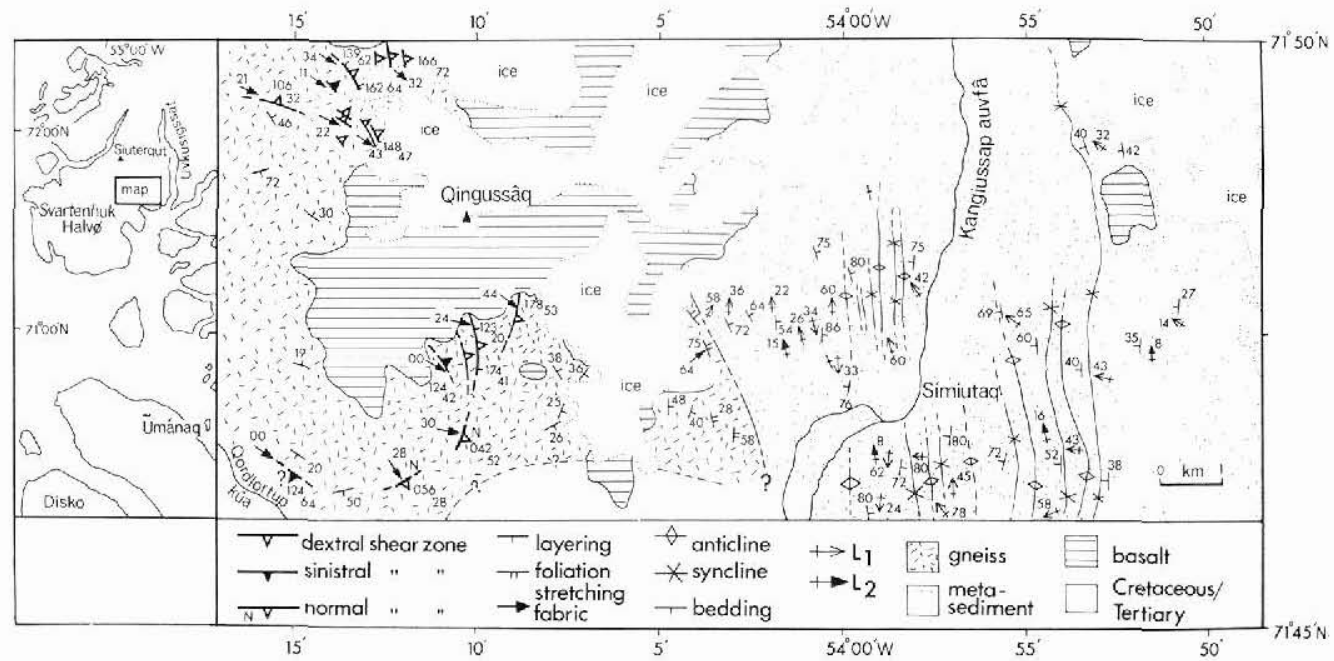

Fig. 6. Structural map of part of the study area. $L_{1}$ is the intersection between bedding and the first cleavage. $L_{2}$ is the direction of the second fold hinges. The term 'foliation' refers to the planar element of the shape fabric. Quaternary deposits are omitted.

tarssuaq Formation which underlies the Nûkavsaq Formation east of Svartenhuk Halvø (Henderson \& Pulvertaft, 1967).

Deformation. There were two important deformation phases of these sediments. The first, $D_{1}$, resulted in tight to isoclinal folding at various scales. The largest scale $D_{1}$ folds have wavelengths of several kilometres and are, in general, upward facing and north-east verging, although reorientation during $D_{2}$ has led to local complications. These folds have relatively undisturbed long limbs, while short limbs contain many medium-scale folds appearing on the map as belts of intense folding on a $100 \mathrm{~m}$ scale. One such belt crosses Símiutaq (fig, 6). The $D_{1}$ cleavage $\left(S_{1}\right)$ is continuous in the shales and fine to coarsely spaced within the sandstones. In less well exposed ground, hinge lines of folds can be mapped out using cleavage/ bedding relationships. The orientation of the cleavage/bedding intersection $\left(L_{1}\right)$ is variable (fig. 6), and as the gneiss contact is approached $L_{1}$ systematically rotates from a shallow north plunge, to a down dip plunge close to the contact over a distance of $1 \mathrm{~km}$.

$S_{1}$ steepens from east to west across the area becoming 'overturned' near the sediment/ gneiss contact. This fan is the main effect of the second deformation $\left(\mathrm{D}_{2}\right)$. It is accompanied by a crenulation with east dipping axial planes and shallow north plunging axes. $D_{2}$ is most intense in west Símiutaq in the hinge of an open $F_{2}$ fold where, in garnet-mica schists, a strong crenulation cleavage has developed. Nearer the sediment/gneiss contact $D_{2}$ is less evident, and within $0.5 \mathrm{~km}$ of the contact is apparent only as an open crenulation of $S_{1}$. East of Símiutaq open medium-scale kink-like $F_{2}$ folds are commonplace. A few distinctive tourmaline-bearing pegmatites cut the Nûkavsaq Formation in a zone west of Kangiussap auvfâ. They are post- $D_{1}$ in age. 
Metamorphism increases from greenschist to upper amphibolite facies westwards towards the sediment/gneiss contact, but details of the relationship between deformation and metamorphism cannot be given before thin sections have been studied. The sediments coarsen as the grade of metamorphism increases. Some horizons within $0.5 \mathrm{~km}$ of the contact are very coarse grained and contain leucocratic migmatitic schlieren lying parallel to $S_{1}$ and weakly crenulated by $D_{2}$. The migmatitic rocks contain sillimanite.

\section{Gneisses}

Within the gneisses the foliation trace has a concentric pattern defining a dome-like structure (fig. 6). Tonalitic gneisses crop out towards the centre of this structure, becoming progressively invaded by irregular granite veins and sheets towards the contact with the sediments. These veins may come to form over 50 per cent of the rock.

The appearance of these rocks is strongly affected by deformation which occurred after the granites were intruded. The least deformed tonalitic gneisses are in granulite facies. Such rocks may be structurally isotropic, with irregular tonalitic veins isolating dioritic and basic schlieren. However, they frequently possess a prominent layering produced by a deformation which pre-dates emplacement of the granites. Elsewhere, amphibolite facies tonalitic gneisses occur, which seem to be derived by retrogression from gneisses like those described above. Within $2 \mathrm{~km}$ of the sediment/gneiss contact, however, the gneisses are so extensively invaded by granite, that even where later deformation is low, the earlier characteristics of the gneiss are obscured. Such rocks are called granitic migmatites.

Where granite sheets cut granulite facies gneisses, retrogression occurs near the contacts. However, where unretrogressed layered gneisses, together with the sheets and this contact zone, are folded harmonically during later deformation, hypersthene and clinopyroxene recrystallized to form a planar fabric congruent with that in the sheet and parallel to the axial plane.

Contact with the sediments. The contact between sediments and gneisses is concordant, and dips away from the gneisses at $75^{\circ}$. It is mapped at the first occurrence of grey biotitefeldspar augen gneiss, but a contact zone exists comprising intensely deformed bands of this gneiss together with coarse hornblende gneiss and fine-grained granular biotite-hornblende gneiss, reminiscent of recrystallized psammitic members of the Nûkavsaq Formation. Amphibolite and quartzite bands are also present, which may belong to the Qeqertarssuaq Formation. An amphibolite dyke with relict sub-ophitic structure occurs in the contact zone. All these rocks are cut by weakly deformed tourmaline bearing pegmatites.

As described above, $F_{1}$ folds in the Nûkavsaq Formation are upward facing and north-east vergent to within $100 \mathrm{~m}$ of the contact with the gneisses. The occurrence of members of the Qeqertarssuaq Formation within the contact zone shows, however, that a syncline may be present in highly deformed rocks near the sediment-gneiss contact.

Deformation gradually decreases away from the contact and the outward dip of the shape fabric and the layering lessens. Deformation dies out $1.5 \mathrm{~km}$ into the gneisses, where the structurally anisotropic granitic migmatites exposed are probably the parents of the highly deformed biotite-feldspar augen gneisses nearer the contact. 
Ductile shear zones within the gneiss. The gneisses are deformed by a system of curved outward dipping ductile shear zones which seem to define a concentric system (fig. 6). The stretching fabric plunges consistently south-east suggesting that this pattern is not due to later folding. The orientation of the shape fabrics and the movement sense of the important shear zones are shown on fig. 6 . The data are consistent with the gneisses in the central part of the dome having moved obliquely upwards with respect to those outside the shear zone system.

The widest shear zones contain up to $20 \mathrm{~m}$ of platy gneiss. In the south-west part of the system the least deformed rocks occurring between shear zones are granitic migmatites, and broad zones of moderate and low strain with many minor folds can be mapped within the system. In the north-east in contrast, where the least deformed rocks are in granulite facies, only narrow zones of moderate and low strain flank the shear zones.

A few planar, parallel-sided basic dykes cut the least deformed gneisses. Most are weakly foliated amphibolites, though sub-ophitic texture is occasionally preserved. These dykes change trend and follow shear zones where the two intersect. Much more irregular, though not necessarily more deformed, dykes are common in the shear zones. Tourmaline-bearing pegmatites post-date formation of the shear zone system.

Gneiss in the centre of the dome. Upper amphibolite facies tonalitic gneiss in the centre of the dome-like structure contains relatively few granitic veins and sheets. In the exposure the layering is constantly orientated and the gneisses are often quite platy although no discrete shear zones are recognised. The granite sheets are concordant and isoclinally folded. Axial planes of these folds are subparallel to the layering which defines a rather open dome structure (fig. 6).

\section{Structural history}

(1) Granite sheets intrude tonalitic gneisses locally, at least, in granulite facies. This activity is concentrated within a few kilometres of the gneiss/sediment contact.

(2) Deformation related to dome formation begins, together with some recrystallization within the granulite facies rocks where hypersthene and clinopyroxene are preserved after (1).

(3a) An intense upper amphibolite facies shear zone develops at the gneiss/sediment contact.

(3b) The shear zone system within the gneisses forms.

(3c)Formation of isoclinal folds in the central part of the gneisses. Axial planes of these folds and layering define an open dome-like structure. This deformation was probably accompanied by retrogression to upper amphibolite facies.

(3d) Intrusion of basic dykes.

(4) Intrusion of tourmaline bearing pegmatites.

The temporal relationships of events $3 a-c$ remain uncertain. Dyke intrusion probably occurred at various times during formation of the dome. 
Metasediment - gneiss relationships north of the study area

A helicopter reconnaissance east of Suiterqut (16 km north of Qingussâq) revealed a contact of fundamentally different character to that described. Here a broad zone at the contact consists of a network of granitoid veins and sheets cutting the sediments and appears to pass transitionally into homogeneous granitoid rocks. A short investigation in Uvkusigssat $\left(71^{\circ} 03^{\prime} \mathrm{N} ; 51^{\circ} 53^{\prime} \mathrm{W}\right)$ revealed that the granitoid rocks are deformed, and lithologically very similar to the post $D_{1}$ tourmaline bearing pegmatites described in the study area.

Acknowledgements. Logistical support was provided by $N$. V. Ussing with Bjarne Eriksen as skipper, and by a Greenlandair Charter jet-ranger helicopter on charter to Greenex a/s Mârmorilik.

\section{References}

Henderson, G. \& Pulvertaft, T. C. R. 1967: The stratigraphy and structure of the Precambrian rocks of the Umanak area, West Greenland. Meddr dansk geol. Foren. 17, 1-20.

Rosenkrantz, A., Noe-Nygaard, A., Gry, H., Munck, S. \& Lauersen, D. 1942: A geological reconnaissance of the southern part of the Svartenhuk peninsula, West Greenland. Meddr Grønland 135(3), 72 pp.

Steenstrup, K. J. V. 1883: Bidrag til Kjendskab til de geognostiske og geographiske Forhold i en Del af Nord-Grønland. Meddr Grønland 4, 173-255.

Geologisch Instituut der Universiteit van Amsterdam,

130, Nieuwe Prinsengracht, $1018 \mathrm{VZ}$ Amsterdam, The Netherlands.

\section{Reconnaissance study of uranium and fluorine contents of stream and lake waters, West Greenland}

\section{Agnete Steenfelt and Else Dam}

The present study forms part of a current investigation on the applicability of geochemical methods in mineral exploration in Greenland.

The sampling programme of 1981 comprised three parts:

(1) A helicopter supported, low density, regional sampling (1 sample/30 $\mathrm{km}^{2}$ ) of stream water and stream sediment in the area covered by map sheet 66 V.2, south-east of Søndre Strømfjord. A total of 207 water samples was obtained. 